\title{
Study on Root Causes and Countermeasures for the Weakening Credibility of Local Government in China
}

\author{
Xiaoli Zhang \\ Management College, China West Normal University, Nanchong Sichuan, 637009, China
}

\begin{abstract}
Keywords: Urbanization, local government, Credibility, weakening, Root causes and
\end{abstract} countermeasures

\begin{abstract}
Government credibility, carried by government administrative behavior, is actually rooted in public appeal, and embodied in the government's political legitimacy and social influence. At present, the weakening credibility of local government has become an obvious problem, which is mainly manifested in inaccurate positioning of government functions, inappropriate behaviors of government members, lack of expected decision making, private government information, low working efficiency, and other aspects. Thus, it is necessary to establish a scientific democratic mechanism, enhance the management intensity, consistently optimize the management system, and improve the image of government.
\end{abstract}

\section{Introduction}

The sustained development and transformation of society may properly weaken the credibility of local government. Government administrative behavior is closely related to government credibility information and the public's attitudes towards the government. Therefore, local government credibility has to be strengthened, in order to create a hardworking, honest and efficient government, and fully understand the local government.

\section{The credibility of local government in China}

The nature of government is reflected in publicity, which is the goal of the modern national government. The government's basic interest is started for the maintenance and development of social benefit. It aims to provide fair, efficient, and high-quality services and products for the society. Effective supply of public products to the society is an embodiment of social public interests, and also a main part of the development of democracy and civil society, with the basic purpose of cultivating citizens' democratic political spirit and social development space. Fundamentally, the government publicity will limit the government behavior value and purpose. Thus, the government needs to implement behaviors which are oriented by public interests to realize its commitment and win the trust of the public. With the advent of modern times, the public constantly improves their political awareness and right consciousness. In the face of crisis, traditional way to believe the government will not win any trust or comfort mood. Due to the progress of network, more and more people have the tendency to participate in social events, and most of the mass incidents are highly under public interests. For example, in the requisition of rural land, incomplete acquisition procedures, unreasonable allocation of land expropriation compensation, low compensation, inadequate compensation fees, etc.; non-transparent policy, non-uniform standards, low compensation standard during the process of demolition; many enterprises would deduct or delay workers' salary, or refuse to pay worker's compensation, health and pension insurance. The above factors are playing an important role in eroding the government credibility.

\section{Weakening Government Credibility}

The government loses credibility because of lack of expected decision-making.

Firstly, without stable and consistent policies, a new government may perform totally different from the last one. Inconstant policies prevent the public from reasonably expecting the government 
behavior. Thus, the government has the obligation to reasonably adjust related policies according to the actual situations, and maintain the consistency, stability and continuity of basic policies. Secondly, many local governments have raised protection policies, which are not consistent with the national public policy system, leading to loss of public trust. Some local governments can always find a way to cope with the national policies; policy, law, and department restricts each other; the local governments refuse to mend their ways after repeated orders and education. These issues have given rise to credit problems. Besides, local governments failed to effectively implement the policies, so they lost credibility [1].

\section{Improper behaviors of governmental personnel.}

Government should stand for the public interest, raise the service consciousness, implement the service function, and wholeheartedly work for the people. At present, however, a lot of local government officials lack of professional ethics; they refuse to handle people's problems in a timely manner, until the situation has been deteriorated. What's worse, bureaucracy would greatly damage the government's credibility.

\section{Inaccurate positioning of government functions.}

Unreasonable performance may reduce the government authority. Due to the continuous development of market economy, public management function has become more and more prominent.

"Small government and big society" is a basic development trend of the future government. In the actual implementation process, many local governments keep a negative attitude. This will seriously affect the public emotion, and the government may lose the support and trust of the public. Government inaction, in fact, means the government fails to fulfill the corresponding responsibilities even if it has obligations and responsibilities to implement administrative actions. The government would take negative and passive ways to avoid risks, and this will cause loss of government credibility. Government inaction cannot effectively guarantee the rights of legal persons, but it will decrease the government credibility to a certain extent. As a result, it will reduce the public understanding of the government position and image, and even the credibility. Government misconduct is another serious problem. The fundamental purpose of policy implementation is to protect the public interests, and improve the public welfares. However, in the actual implementation, unreasonable decisions may be raised without scientific strategic support. This may affect the public interest, and reduce the government credibility.

\section{Low working efficiency in government.}

Inadequate coordination function hinders local governments from understanding the most realistic concerns of the public, or solving them in time. When a problem happens, many departments prefer to pass the buck to others. This seriously reduces the working efficiency. According to relevant data, $46 \%$ of the public believe that government has partially or rarely performed its functions; $40 \%$ of the public argue that the government failed to reasonably regulate and rectify behaviors that may do harm to economy; $81 \%$ of the public argue that the government efficiency is not satisfactory. When government is performing administrative actions, the administrators have the right to explain the policies and laws, and they have a certain degree of discretionary power in the actual implementation. However, some government officials take advantage of the imperfect system during social transformation to make benefits for themselves, not the public. Many people may abuse the power of rights group to unjustly allocate social interests. That will seriously affect the public interest, reduce the public trust in government, and affect the status of the government [2].

\section{Private government information.}

Government has the obligation to disclose the relevant policies and work, so as to ensure that the government functions can fully reflect the public opinion and the actual situation. However, many government agencies like to keep their information and policies in private, and the public cannot get access to the situation of actual implementation. This has severely affected the government supervision and management, and caused the phenomenon of corruption, or black-box. Government work can't go smoothly. 


\section{Countermeasures to improve the government credibility}

With the accelerating urbanization process, it will be an important issue to increase government credit, enhance the credibility, and improve the overall image of the government in future. This paper mainly analyzed the countermeasures of improving the government credibility from the following aspects.

\section{Perform official duties according to laws, and strengthen the management system.}

Imperfect rights system, laws and regulations are playing a mojor role in weakening the government credibility. Abusive administrative power has significantly affected the government executive ability. Therefore, establishing an improved system of laws and regulations is an effective way to increase the government credibility. Government by law, one kind of management order and status, is an applicable and pervasive approach in governing the society, and a guarantee and foundation for measuring the rule of law, as well. Taking government behavior into the range of rule by law will improve the transparency to a certain extent. The increase of government transparency will improve the public trust in government, and construct the government credibility effectively. Law should limit the administrative power. Laws and constitution are the foundation for the government to exercise its rights, so arbitrarily expanded organizations are not allowed. The connotation of administration by law: restriction, equality, protection and responsibility under the rule of law. Government by law will build a trust relationship between government and the public, and increase the government credibility. According to the relevant national laws and regulations: the People's Republic of China shall govern the country by law, and construct a socialist country. Since the strategy of governing the country by law was established in 1997, the administration degree has been improved to a great extent. At the present stage, there is still a huge gap between the construction of the country under the rule of law, so we should constantly improve the administrative enforcement of law, administrative legislation, and supervision and administration [3].

\section{Improve the public policy, and intensify the democratization mechanism.}

Scientific and reasonable public policy is the basis and premise of the government credibility. Thus, scientific policy procedures should be formulated, including social problems, policy discussion, policy planning, policy making, information disclosure, universal participation, response and negotiation, policy confirmation, legal consultation process, and other procedures. This will effectively improve the quality of policy implementation, and promote the clarity, rationalization and legalization of the policy, so as to effectively improve the public trust in government. Therefore, the government should establish the hearing system and publicity system. For policies associated with the public interest, the government should establish the hearing system and publicity system in the implementation, so as to make the policy contents and items known to the public, and ensure that the public right of participation. According to a large number of data, the hearing system and the decision publicity system can enhance the transparency in government decision-making, and enable the public to fully participate in the decision making process. Thus, the decision making process is more democratic and scientific. In addition, it plays a certain role for the public to supervise and manage the implementation of the decisions, so it will achieve very good social effects.

\section{Optimize the management system, and improve the government working efficiency.}

Administrative management is another important factor influencing the government credibility. In order to effectively increase the government credibility, we need to start from the management system. Based on the basic principles of efficiency, unity, simplification, reasonably optimize and streamline the government administrative management mechanism. This is useful to clear the rights and responsibilities of government departments, establish a standardized, coordinated, efficient, clean, transparent and fair management mechanism, and provide high quality services for social development. With progress of the times, keeping the public informed of the government affairs has become a basic requirement of the government management. It is an effective way to improve government management ability, and it is also a basic trend of modern, highly efficient administration. Thus, it is playing a significant role in enhancing the government credibility and cultivating the public awareness. According to the basic principles of government by law and by the people, the public 
power is required to be supervised by the public. Decisions related to public services and public affairs are required to be open to the public, in order to improve the legal system and enhance the overall government credibility. We also should promote the development of electronic government, which is designed to further promote the openness and transparence of information, and use the online government to effectively manage public affairs. It can be analyzed from the following three aspects: firstly, improve the overall service function and quality of administrative information; secondly, enhance the integration of administrative information resources; thirdly, increase the government's working efficiency. There are four factors influencing the working efficiency of government: firstly, rationalize the implementation of government power structure; secondly, reasonably set government administrative organization structure; thirdly, the rationalize the government administrative method; forthly, constantly innovate government coordination mechanism and enforcement system [4].

Improve the quality of civil servants, and change the public image of government.

According to the theory of modern management, human resource comes first in management activities, because it is the most active and the most important factor in management. The center of the above management theory is people oriented, so a superior management relies on excellent managerial personnel. From the perspective of government, civil servant is not only the person in charge of implementing the government public decisions, but also the representative of the government's image. Therefore, it is a critical method to enhance the government credibility through cultivating high-quality civil servants and changing the image of the government. At present, administrative quality and moral quality are playing a critical role in improving the overall quality of public service personnel, mainly including the following two aspects: occupational skills and moral quality. From the aspect of moral quality, civil servants ought to love the job, promise to dedicate to the job with a high degree of discipline and sense of responsibility, and stay reliable and honest. From the aspect of occupational skills, the government should acquire a set of management way, techniques and guiding thoughts to implement the public policy decisions. In order to achieve highly efficient training effects, the government should develop different abilities of civil servants for different positions and professions. The most essential thing is to analyze from the moral quality, and make sure that everyone behaves honestly and rightfully. Moral accomplishment mainly includes two aspects: one is ability accomplishment, mainly including social ability, observation ability, organizing ability, commanding ability, expression ability, coordinating ability, thinking ability, etc.; the other one is knowledge accomplishment, mainly including theoretical knowledge, social knowledge, professional knowledge, and legal knowledge [5].

\section{Conclusion}

In view of above points, the process of urbanization may undermine the credibility of local government in our country to a certain extent. The complex social foundation may make the contradictions more prominent. The public begins to pay more attention to issues which can satisfy their fundamental interests. In recent years, with the rising living standards, as well as the development of economy and social security, our country has obtained some effects. At present, however, there are still some problems existing in most of the public. The above achievements can effectively reduce the problems, so as to enhance the government credibility, and provide a guarantee for the further research of local government credibility.

\section{Acknowledgments}

This paper is a key project of the humanities and social sciences of Sichuan Education Department. Project number: 12SA132. 


\section{References}

[1] Meng Zhen, Shu Juan. Enhancement of the Credibility of the Local Government under Public Crisis Management . Journal of Xiangtan University (philosophy and social sciences edition), 2013,37(6):101-104.

[2] Liu Guohua, Wei Guanglin. Enhancement of law enforcement credibility in the new urbanization process . Journal of Northern Economy and Trade, 2014(9):65-66.

[3] Li Donglin. A study on performance evaluation mechanism of new urbanization construction under the perspective of finance . Journal of Shandong Social Science, 2015(7):167-171.

[4] Gong Peiqian, Zhang Honxia. Choices for enhancement of judicial credibility-taking the advancement of procedural justice as the breakthrough point . Journal of Heihe University, 2013, 4(3):23-27.

[5] Zheng Gantian. Grand blueprint of optimal allocation of education resources in minority regions evaluation of the forecast report of basic education resource allocation in Enshi under the background of new urbanization . Pioneering with Science \& Technology Monthly, 2015, 28(8): cover 3. 